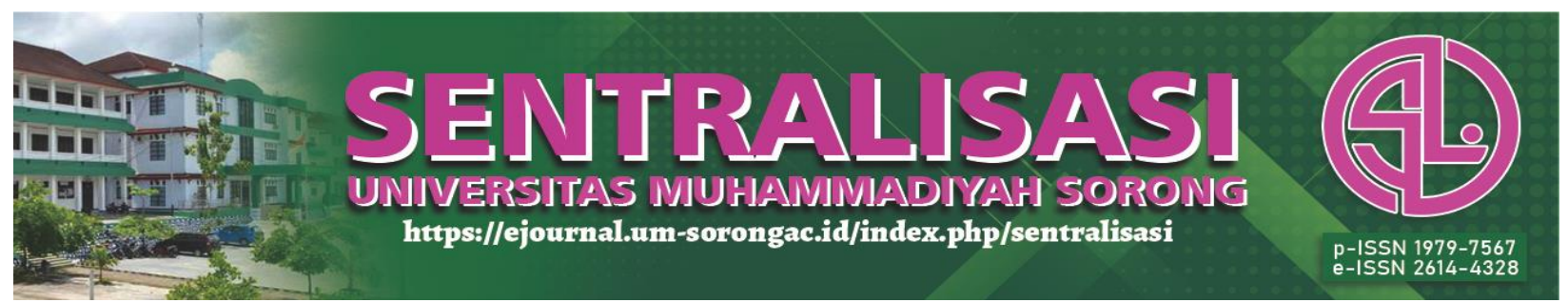

\title{
Fiat Money Inconsistency and the Return of Dinar-Dirham as a Medium of Exchange in the Community
}

\author{
Chairul Iksan Burhanuddin ${ }^{1 *}$, M Hidayat ${ }^{2}$ \\ ${ }^{1,2}$ Faculty of Economics and Business, Universitas Muhammadiyah Makassar, Indonesia \\ Email: *chairul.iksan@unismuh.ac.id, \\ *corresponding author
}

direvisi: 16/06/2021 dipublikasikan: 30/06/2021

\begin{abstract}
Abstrak. Virus Corona atau disebut sebagai covid-19 telah menyebabkan berbagai macam efek negatif, khususnya pada bidang ekonomi. Melonjaknya tingkat pengangguran, terkontraksinya pergerakan nilai rupiah dan mata uang lainnya berdampak pada pergerakan perekonomian yang semakin lesu dalam beberapa waktu hingga kepanikan nilai emas yang harganya terus naik dalam beberapa bulan terakhir. Metode kualitatif digunakan dengan cara mendeskripsikan secara ilmiah mengenai dampak dari kasus virus Covid 19 terhadap pergerakan nilai mata uang dan nilai emas. Hasil penelitian ini menunjukkan bahwa virus Covid 19 memberikan dampak yang cukup negatif dalam sektor perekonomian, khususnya pada pergerakan nilai mata uang dan nilai emas. Pergerakan nilai rupiah mengalami kontraksi hingga menyentuh Rp.14.000 sementara nilai emas cenderung naik secara signifikan. Nilai emas yang terus naik menunjukkan tren yang positif terhadap kemungkinan implementasi penggunaan mata uang dinar dan dirham secara legal di masyarakat. Emas tidak lagi dipandang sebagai Save Haven, akan tetapi perannya sebagai penyambung kegiatan muamalah (jual-beli) di masyarakat semakin nampak. Ada kepanikan dan secara psikologis mengganggu para pelaku ekonomi dan masyarakat dalam menyikapi kejadian ini.
\end{abstract}

Kata kunci: Uang Fiat, Ekonomi, Dinar, Dirham.

Abstract. Coronavirus or referred to as covid-19 has caused various kinds of negative effects, especially in the economic field. The soaring unemployment rate, the contraction in the value of the rupiah and other currencies has resulted in an increasingly sluggish economic movement in recent times until the panic of the value of gold continues to rise in recent months. The qualitative method is used by scientifically describing the impact of the Covid 19 virus case on the movement of currency and gold values. The results of this study indicate that the Covid 19 virus has a quite negative impact on the economic sector, especially on currency and gold value movements. The movement in the value of the rupiah contracted to touch Rp.14,000 while the value of gold tended to rise significantly. The rising gold value shows a positive trend towards the possible implementation of the legal use of the dinar and dirham currency in the community. Gold is no longer seen as a Save Haven, but its role as an extension of muamalah activities (buying and selling) in the community is increasingly visible. There is panic and psychologically disturbing economic and community actors in responding to this incident.

Keywords: Fiat Money, Economy, Dinar, Dirham.

Chairul Ihsan Burhanuddin 


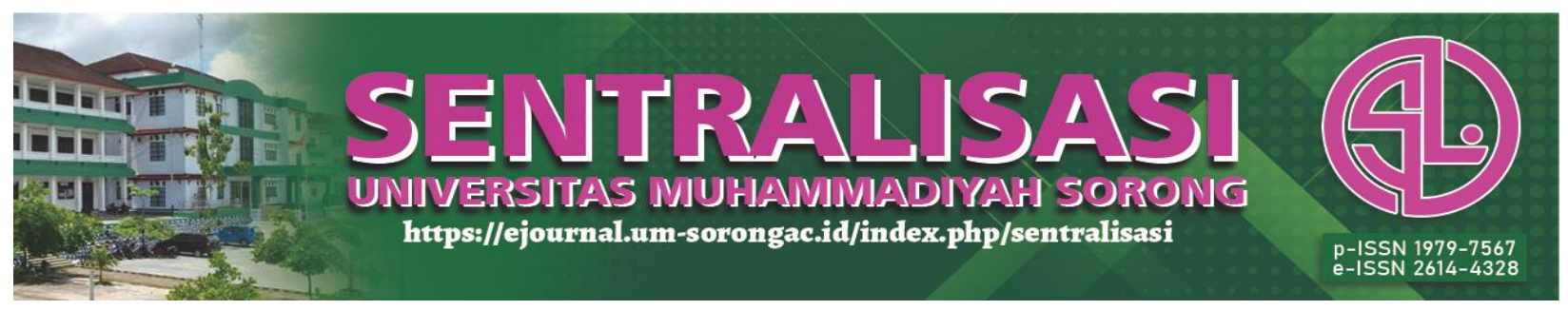

\section{Introduction}

One of the thoughts put forward by the Federal Reserve is that it only maintains that the interest rate is too low and that it makes it too easy to share the debt to increase its uncertain level. Some argue that the deregulation of financial institutions is too excessive, while others argue that government policy encourages the poor even if they aspire to own their own homes, which is a major factor in the economic bubble in the housing sector (Cai and Warnock 2006).

Further economic problems are related to the idea of income (Shinohara and Gunji 2001). An important concept that causes many misunderstandings is the concept of money demand. How many monetary assets are actually needed. The demand for money is not directly integrated with measures of wealth. In everyday language, it often happens that everyone assumes that they want more money, that the desire to have money is due to unlimited things. But what people mean in this case is the demand for wealth (ownership) or what can be referred to as "demand for wealth", to own goods and services, but not the demand for a medium of exchange is not what is meant like that. Money actually has no direct use value (Yasutomi 1995). However, goods and services that have a use value. So, not everyone wants to hold all his wealth all the time in the form of money. At least have to exchange some money for food, clothing, and accommodation, thus converting some of the money (his possessions) into goods that have use value. And even a person who has sufficient wealth to acquire all of the consumer goods he or she wants may not retain the remaining wealth entirely in the form of money but invested in debt or claim equity or other investment goods (Schlichter 2014).

Conventional financial crises are changes that occur so quickly that it is very difficult to predict future economic conditions (Roth 2009). Such is the current state of the economy. From an economic perspective, one of them is the use of currency. The currency we use today is referred to as fiat money (Kocherlakota 1998) issued by the Central Bank. The role of the central bank is to present fiat money in the form of notes and coins in the community. In Indonesia, the Central Bank that plays a role in distributing rupiah currency is Bank Indonesia. Since the 1998 monetary crisis phenomenon, the value of the rupiah against the US dollar has experienced a significant 


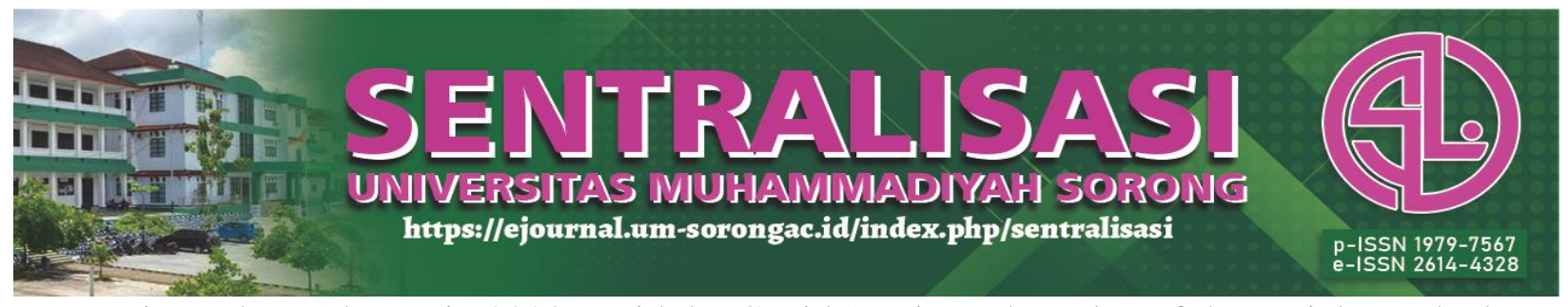

contraction. The peak was in 2020, amid the Covid 19 virus, the value of the rupiah touched Rp. 14,387 (Indonesia 2015).

There are problems caused by the capitalist economic system. Among them, the value of the currency continues to decline, while the prices of goods and services continue to rise (Ricks 2011) causing economic thinkers to start thinking about solutions to these problems. One of the solutions offered is a sharia-based economy. In Islam, the buying and selling system adopted has differences from conventional economics, including the use of currency. Islam recognizes the dinar and dirham currencies in carrying out buying and selling transactions (Meera 2002). Gold and silver are used because they have a globally universal content and essence value, can be applied all over the world.

In the development of the times, it was the capitalists who made gold and silver not only as a medium of exchange but also as trade in merchandise. Replacing the role of gold and silver as a medium of exchange. Until slowly gold dinars and silver dirhams were replaced with fiat money (paper money). Paper money recognized by many capitalists can solve problems, facilitating transactions cannot solve problems, because it does not have standards recognized by the world. This value exists because it is held by those who have the authority to issue paper money in contrast to gold and silver which have a value attached to the object.

The above situation gave rise to the idea of reusing the gold dinar and silver dirham since several countries in Southeast Asia and several other countries. The country experienced an economic crisis in 1997/1998 and in recent years. The gold dinar and silver dirham are believed to be able to overcome this, referring to the idea of returning the gold supply to the actual money system. The idea by some economists, the application of Islam is not easy because the world economic system is interrelated and influential. However, it is not impossible to restore the function of the gold dinar and silver dirham as a medium of exchange in transactions, bermuamalah, especially in transactions like this there is a value of worship in it, which was taught by the Prophet Muhammad, and several verses of the Koran also explain the function of gold and silver. From this concern, several groups worked together to restore the function of the Gold Dinar and the Silver Dirham to form a community called the Dinar-Dirham User Community. With the 


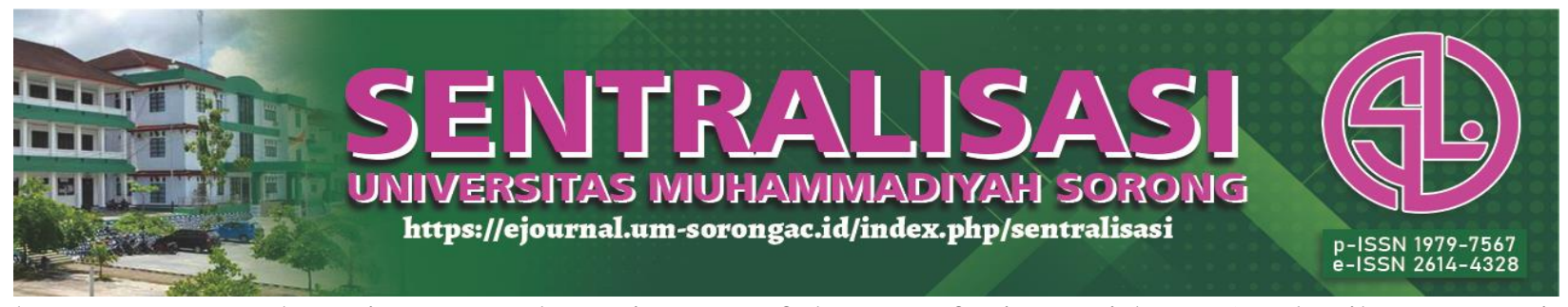

hope to restore the existence and consistency of the use of Dinar-Dirham (Mulatsih, Ratnasari, and Saepuloh 2019).

\section{Research Methods}

Methods This research uses a qualitative approach by applying library research methods (Library Research). Library research is research that uses literature as an object of study. The data used in this study is in the form of secondary data, namely books, scientific journals and other information from the internet which is considered valid. Meanwhile, to answer the problem, this research will use the method of content analysis by providing data to answer the problem. So that it can reveal the problems and solutions in this research.

\section{Results and Discussion}

\section{Fiat Money}

Each crisis has different causes, all of which boil down to human failure, none of which is linked to the capitalist system itself. But crises have repeated themselves periodically over the last two hundred years. Conventional economists must deny that crises are inherent in the social form of capitalist production, since all economic theory is built on the premise that the capitalist system is self-regulating, the main task of the theoretical economist is to identify the minimal conditions under which such self-regulation will be maintained, so that any breakdown will be identified as a result of extraordinary deviations from the norm (Aglietta 2000). One of the products of the capitalist economy is fiat money.

Fiat money is government-issued currency that is not backed by a physical commodity, such as gold or silver, but by the government that issued it. The value of fiat money comes from the relationship between supply and demand and the stability of the issuing government, not from the value of the commodities that support it as is the case with commodity money. Most modern paper currencies are fiat currencies, including the US dollar, Euro, Rupiah and other major global currencies (Chen 2019). Fiat money only has value because the government maintains that value, or because two parties to a transaction agree on its value. Historically, governments would mint 


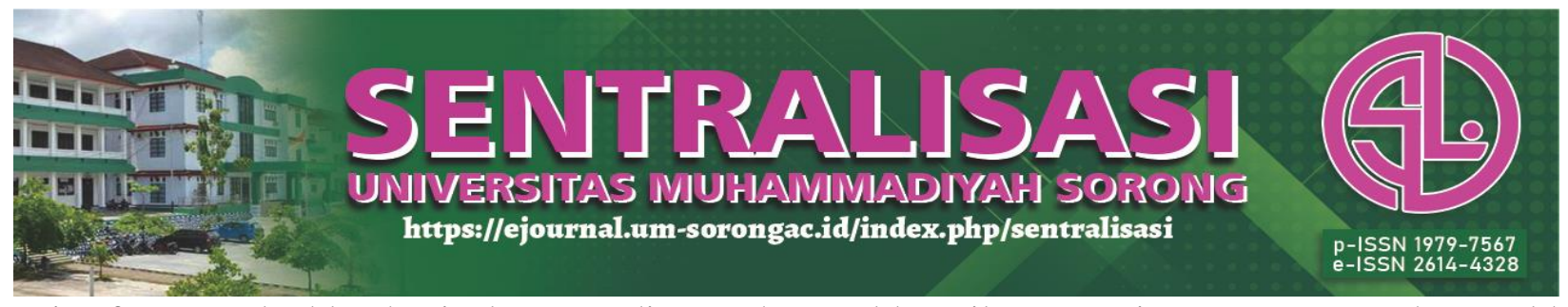

coins from a valuable physical commodity, such as gold or silver, or mint paper money that could be exchanged for a specific number of physical commodities. Fiat money is immutable and nonredeemable. The word "fiat" comes from Latin translated as a decree "must" or "let it be done" or it can also be referred to as an omission of events (Kocherlakota 1998).

Since fiat money is not linked to physical reserves, such as national gold or silver reserves, it runs the risk of losing its value due to inflation or even becoming worthless in the event of hyperinflation. If people lose faith in a country's currency, it no longer has value. That's in contrast to currencies backed by gold, for example; it has intrinsic value because of the demand for gold in jewelry and decoration and the manufacture of electronic devices, computers, and aircraft (Hoppe 1994).

Money is not a creation of the state and not from law, its emergence does not require the approval of the wider community in any form. Money arises because individuals who want to trade then find a useful medium of exchange. The more people start using the same medium of exchange, the more beneficial it will be to them. Money is a social institution that arises spontaneously. Other similar institutions are the clearly defined concepts of private property and property and the rules and standards by which property rights can be transferred. All of these institutions arise because people see the immediate benefits of extended human cooperation, cooperation that extends beyond the family or related entities. Such cooperation enables good business activities and is expected to increase the supply of goods and services for all parties participating in it. Then this wider cooperation requires markets and trade.

Many argue that we need the state, that is, a legalized territorial monopoly of coercion and coercion, for people to use fiat money, to protect property, and to establish laws and regulations that allow it and other activities related to that fiat money. So the assumption assumes that without the state there will be no money, no laws, no rules of exchange, and no value to property. This, of course, is a misrepresentation of the historical record and a misunderstanding of the essential power of the voluntary cooperation of selfish individuals as explained by economics (Bonar 1924). 


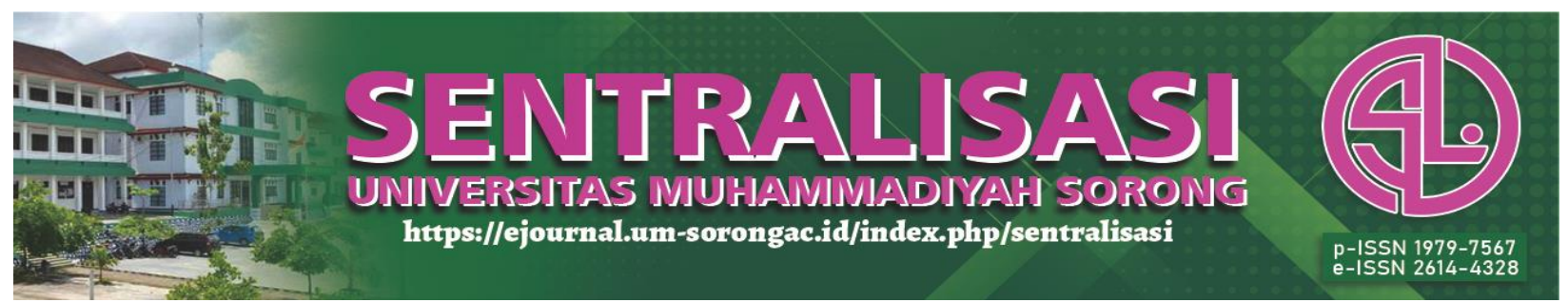

Fiat money and current economic development have disrupted itself. This can be said if we look at the decline in the value of the currency in the last few decades. This can be seen in the graph of the development of the rupiah currency value, for example as follows:

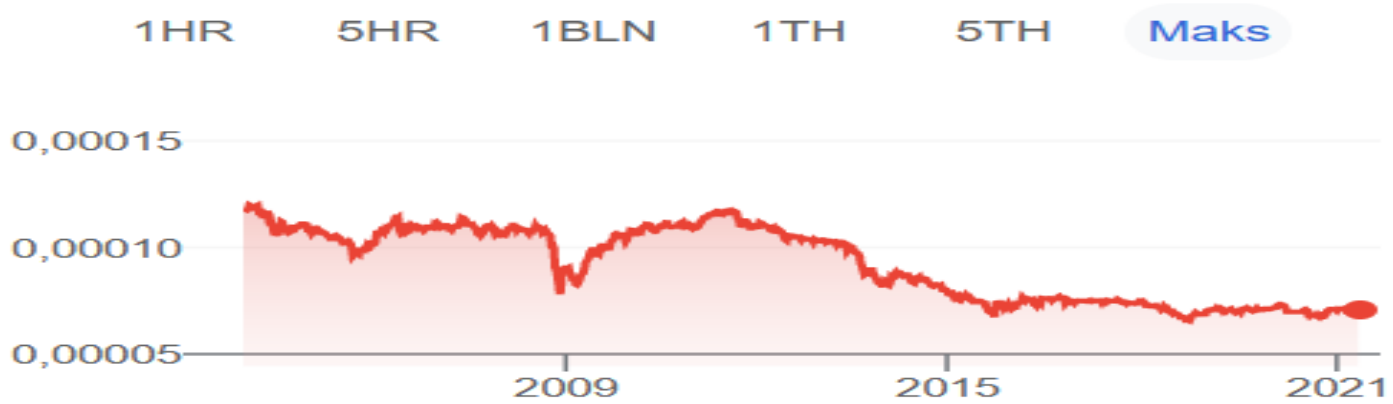

Source: Google Finance, 2021

\section{Image 1. Graph of Rupiah Currency Value Until 2021}

Since 2009, the movement of the rupiah currency has experienced a continuous decline (devaluation). In addition, this is not followed by the ability of the rupiah to offset the increase in the price of goods. So it can be concluded that the decline in the value of the rupiah currency is not in line with the increase in the price of goods and services. This is in line with the definition of fiat money which has no intrinsic value in it, so the value listed on paper or metal does not guarantee its purchasing power for goods and services.

\section{Dinar and Dirham}

Money in its various forms as a medium of trade has been known for thousands of years, such as in the history of ancient Egypt around 4000SM-2000BC. In its standard form, gold and silver coins were introduced by Julius Caesar of Rome around 46 BC. In other parts of the world in the Islamic world, gold and silver coins are known as Dinar-Dirham. The currency of origin of the Dinar and Dirham is the original currency of Rome and Persia which in ancient times were both superpowers in the world. The word dinar in Arabic and Persian comes from the word 


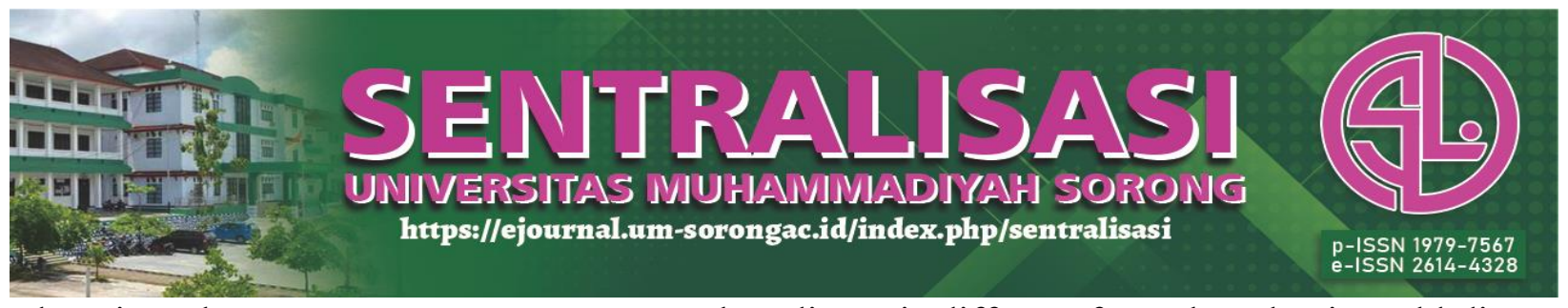

"denarius" the Roman currency. However, the "dinar" is different from the Islamic 'gold dinar'. From another, more philosophical point of view, the dinar currency is called 'Dinar' from the words 'Din' and 'Nar'. Din means religion and Nar means hell. As for the meaning is who takes it with his rights. Considering that it is his religion and on the other hand people who take it without rights then it is hell fire (Mahmoud Arafa 2019). In general, Dinar means 71.5 syar'i gold currency or approximately 4.68 grams, gold coins weighing 4.25 grams and a grade of 22 carats (91.7\%).

The Dinar is also the base unit of currency for Abu Dhabi, Algeria, Bahrain, Jordan, Libya, South Yemen, Tunisia, Kuwait, Iraq which is different from the Dinar as a gold coin. Dirham or dirhm is a unit of currency in several Arab countries as well as Tajikistan. The first is associated with the mass drama units of the Ottoman and Persian empires. The name comes from the Greek currency, the drachma or bidrachm. In Roman times As with the use of the drachma, the dirham was used as a unit of weight in North Africa, the Middle East, and Persia with different values. In its development, the Dirham is a silver currency with a weight of 2,295 grams. Another opinion states that the weight of 1 dirham is equal to 7/10 dinars or equal to 2,975 gram (Srie Nuning Mulatsih and Ratnasari 2018).

In Islamic jurisprudence, gold and silver coins are known as the essential (real) medium of exchange, while copper or bronze money is known as fulus which is a medium of exchange by agreement. Fulus is closer to the nature of paper money that we know today, because it has no intrinsic value (value attached to the physical) of exchange value. The function of money in the perspective of Islamic economics is limited to money as a medium of exchange for goods and services. Islam forbids the accumulation of money and makes money as a commodity, because hoarding money means slowing the circulation of money. This means minimizing the occurrence of transactions, so that the economy becomes sluggish. Islam forbids usury and rejects all kinds of artificial transactions such as what is happening in the money market or the capital market today (Harun 2007).

The use of dinars and dirhams as a medium of exchange for payment and economic transaction activities is based on the following: (1) The Qur'an and the Sunnah mention wealth and wealth in terms of gold and silver (dinar and dirham), (2) Efforts to enforce pillars of Islam is to 


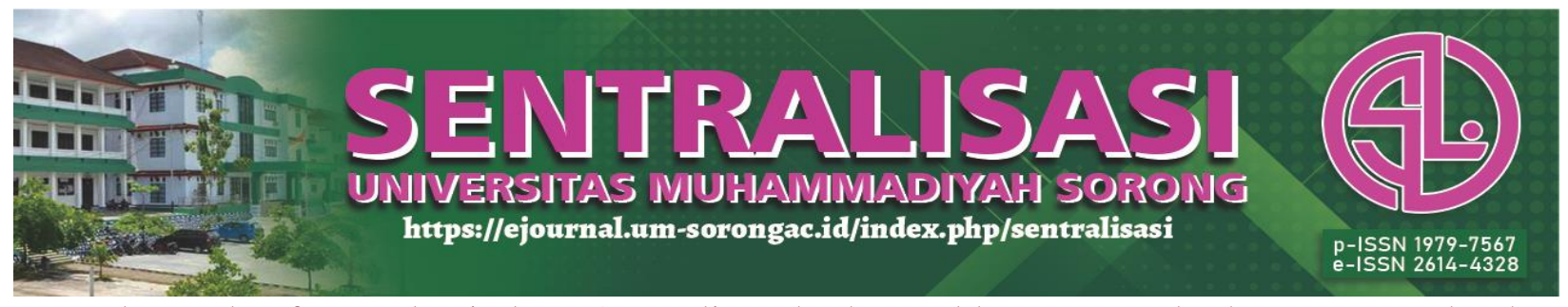

pay zakat and enforce Islamic law. A Muslim who has gold, money and other property that has reached the nishab (measurement of iberat) of gold worth 20 dinars is obliged to pay zakat, (3) Gold money is universal and can be accepted by all parties because the material is gold and is relatively difficult to counterfeit. Gold money has a certain color, grade, and strength that cannot be made from other metals, (4) Gold money can be used as a savings tool whose value is relatively more stable. With gold money, its value does not experience sharp fluctuations, because the nominal value is the same as its intrinsic value, (5) In Islamic economics, the function of money is only recognized as a medium of exchange and a unit of account. Money itself does not provide usefulness or benefit but the function of money that provides usefulness. A Muslim who has gold, money and other property that has reached the nishab (measure of weight) of gold worth 20 dinars is obliged to pay zakat, (6) Gold money is universal and can be accepted by all parties because the material is gold and is relatively difficult to fake Gold money has a certain color, grade and strength that cannot be made from other metals, (7) Gold money can be used as a savings tool whose value is relatively more stable, with gold money its value does not experience sharp fluctuations, because its nominal value is the same as its intrinsic value.

In Islamic economics, the function of money is only known as a medium of exchange and a unit of account. Money itself does not provide usefulness or benefit but the function of money that provides usefulness. Of course this is very different from fiat money. Where the medium of exchange (ifiat money) is very dependent on the nominal listed, but the nominal is highly regulated by the owner of the rules (humans) which in this case is the Federal Reserve (Griffin 2000). Long before the West used money in every transaction, the Islamic world was familiar with this medium of exchange and measurement of value, even the Qur'an explicitly stated that the measuring instrument for value was in the form of gold and silver which were expressed as dinars and dirhams. The Qur'an has clearly mentioned dinars and dirhams, namely in QS. Ali Imran/3:75 as follows: 


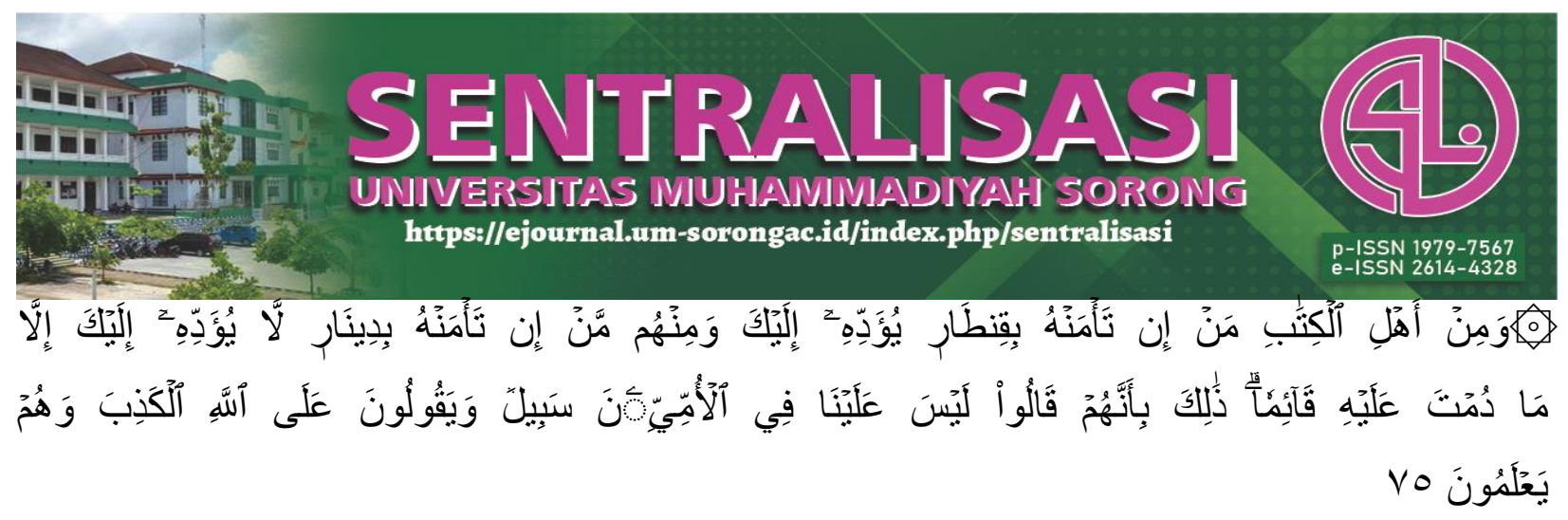

Translate:

Among the People of the Scripture is he who, if you entrust him with much wealth, he will give it back to you; and among them is he who, if you entrust him with a dinar, he does not return it to you unless you always charge it. That is because they say: "There is no sin on us against the uncles. They tell lies against Allah while they know (Kemenag 2012).

Then in other suras also in QS. Yusuf/12:20 as follows:

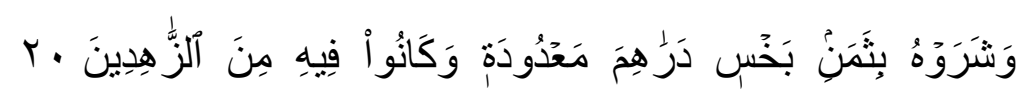

Translate: And they sold him for a reduced price - a few dirhams - and they were, concerning him, of those content with little.

In addition, the use of gold and silver is also mentioned in the Qur'an, namely QS. AtTaubah/9:34 as follows:

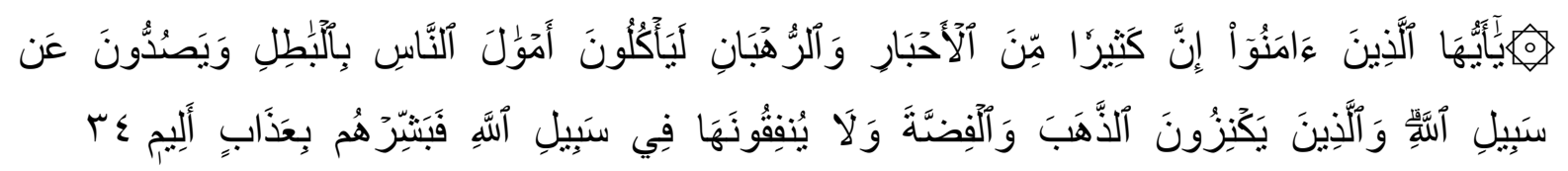

Translate: O you who have believed, indeed many of the scholars and the monks devour the wealth of people unjustly and avert [them] from the way of Allah. And those who hoard gold and silver and spend it not in the way of Allah - give them tidings of a painful punishment.,

Chairul Ihsan Burhanuddin 


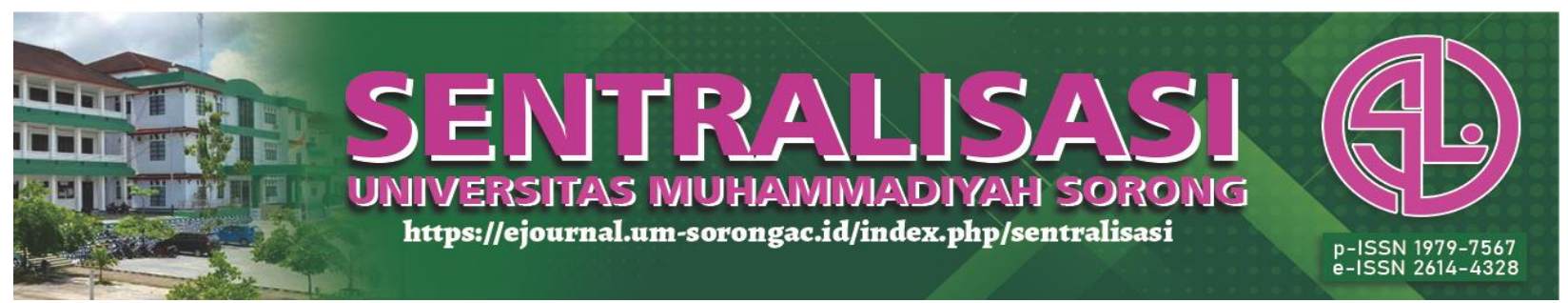

The Qur'an has called for humans to use the dinar (gold) and dirham (silver) long before the creation of fiat currency. So that the use of dinars and dirhams becomes an absolute thing to be immediately realized in the economic system around the world. The consistency of the Dinar (gold) and Dirham (Silver) values has been maintained until now. This can be seen in the following graph:

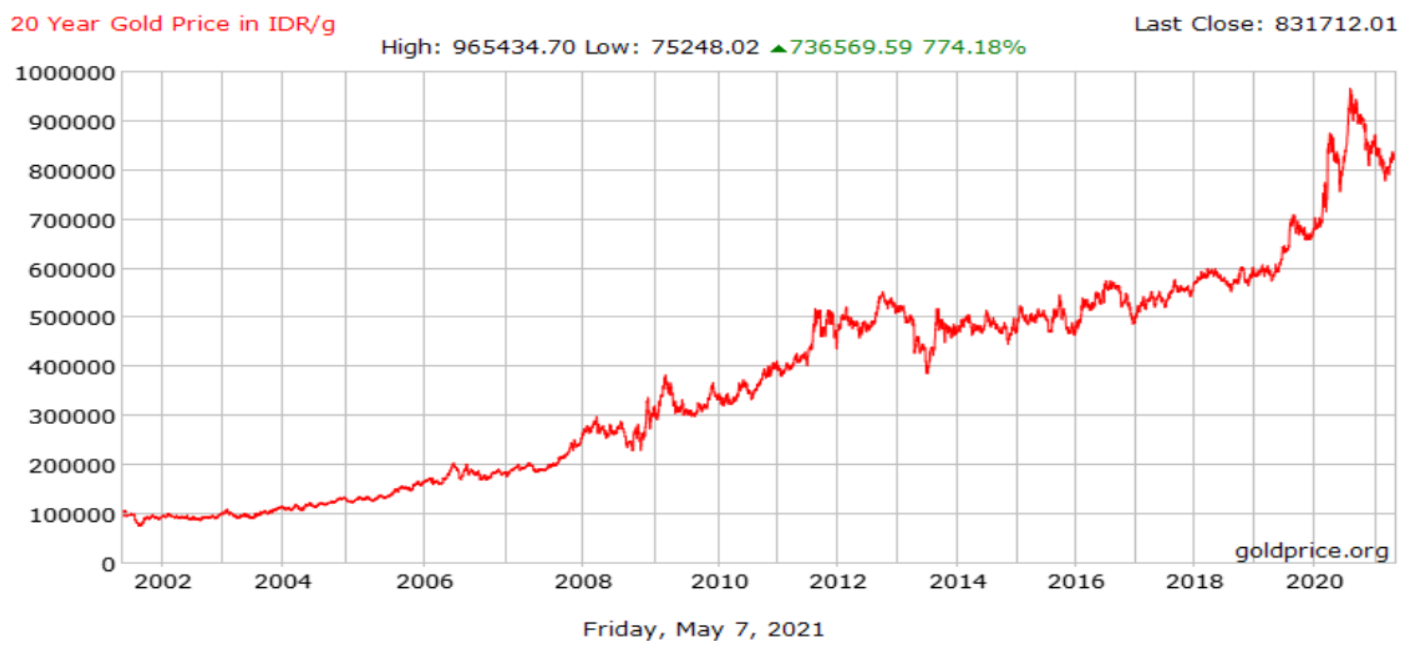

Source: Goldprice.org

\section{Image 2. Gold Value Movement}

The consistency of the value of gold until now still supports the price of goods and services, for example if gold is in the dinar measure since it was determined at the time of the Prophet Muhammad. The price of 1 (one) or 2 (two) goats is 1 dinar. So it is undeniable that the Dinar (gold) and Dirham (silver) are a way out for the inconsistency of fiat currencies circulating around the world.

\section{Fiat Money Inconsistency and the Return of Dinar-Dirham as a Medium of Exchange in the Community}

An explanation of the inconsistency of fiat currency (fiat money) and the dinar (gold) and dirham (silver) can be explained by using the theory of disruption. Disruption theory put forward by Christensen, that disruption is a disturbance that is responded to by a competitive action. 


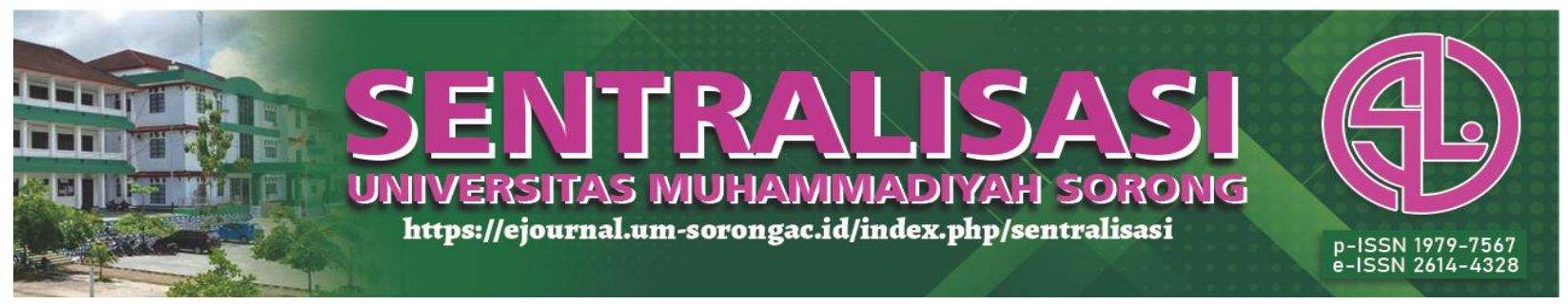

Competitive action in question is innovative action. If one of the entities increases their capabilities, there will be other entities left behind. That is the pattern of disruption that exists in the community and corporate entities (Denning 2016). The existence of the dinar and dirham began to disappear along with the development of the conventional economy. According to the disruption theory, the dinar and dirham are shown to be unable to innovate into the system adopted by conventional economics, one of which is the use of fiat currency.

In the theory of disruption known action innovation, where innovation does not only change something or improve the function of something (goods and services). But innovation makes everything effective and efficient (Essuman, Boso, and Annan 2020). The dinar and dirham have not been able to compete with conventional economic innovations where everything is currently being carried out in the direction of digitalization. This can be described as follows:

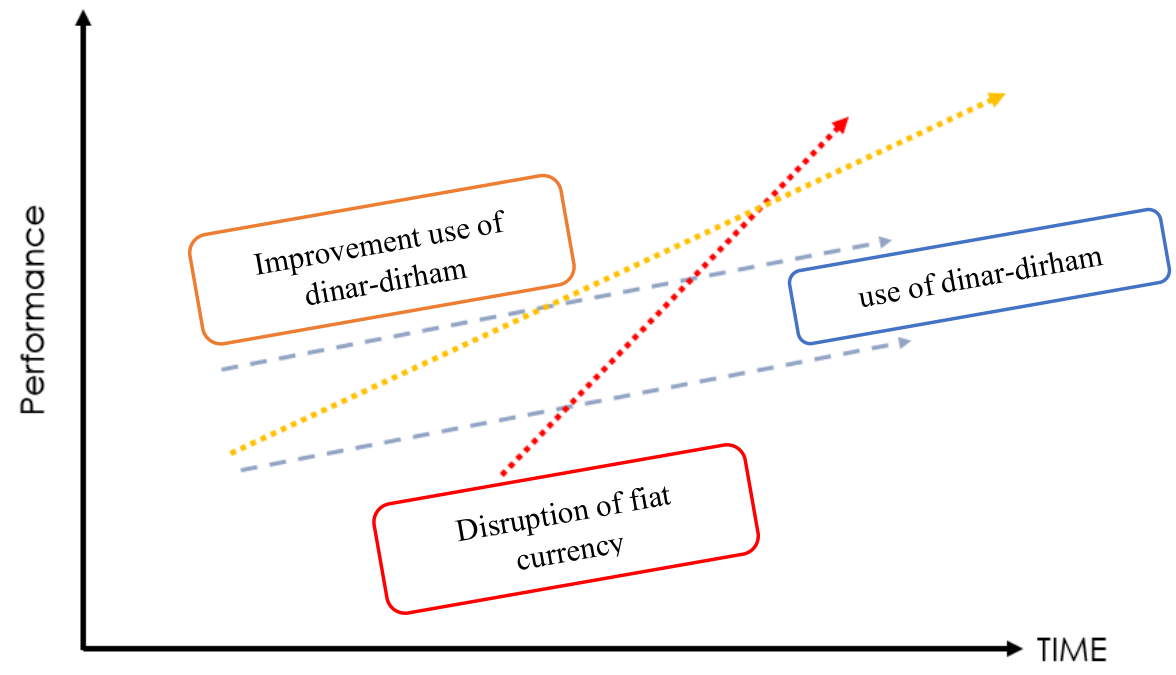

Source: Processed from the disruption model (Denning 2016).

Image 3. Conceptual framework for the implementation of the use of dinar-dirham.

The blue arrows depict the use of dinars and dirhams since their early use. However, the red arrow depicts the emerging conventional economy, including the use of fiat money. So that the red arrow goes beyond the consistency of the use of dinars and dirhams. Economic innovation is marked by the digitalization movement. One form of digitization is the use of electronic 


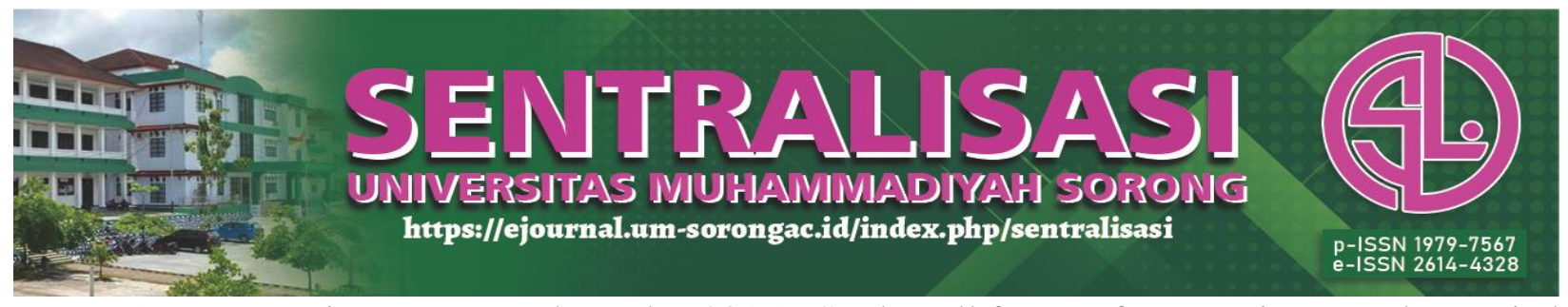

money (Brunnermeier, James, and Landau 2019). So that all forms of transactions can be carried out regardless of time and place. Transactions can be carried out without the meeting of the seller and the buyer. This is not owned by the dinar (gold) and (dirham).

Furthermore, the role of platforms in the digital currency economy is very different from the role of digital networks. In economic literature, platforms are usually two-sided markets where buyers and sellers exchange multiple products. The emphasis is often on how network externalities and cross subsidies between products affect their prices. Instead, the platform's role as an activity aggregator is complementary. In other words, it can be interpreted that the platform is an "ecosystem" where consumers, merchants and service providers interact. The digital payment instruments associated with the platform will effectively combine the functionality of traditional money with the functionality and data of the platform, leading to the merging of money in contrast to the splitting role of digital networks (Afonasova et al. 2019). This development of digitization should be utilized by dinars and dirhams in product development. However, it must still pay attention to the rules and rules in the teachings of Islam. So that the use of dinars and dirhams and the digitization process can go hand in hand without complicating each other. This will certainly be welcomed by the wider community, especially from Muslims.

\section{Conclusion}

Some things that are a concern in the inconsistency of using fiat money and efforts to return dinars and dirhams are the opportunities that should be exploited by related parties. Therefore, the opportunities that need to be considered are as follows: 1) Disruption of the use of dinars and dirhams can be interpreted as their inability to compete and innovate according to the demands of the times. 2) The process of digitizing fiat money is an example of economic development that is adapted to the demands of society and the market. 3) Digitization should be used for dinars and dirhams so that they can be used by the wider community. 4) Implementation of dinars and dirhams to compete with fiat money needs to consider regulations by the local government so that their implementation can be implemented properly. 


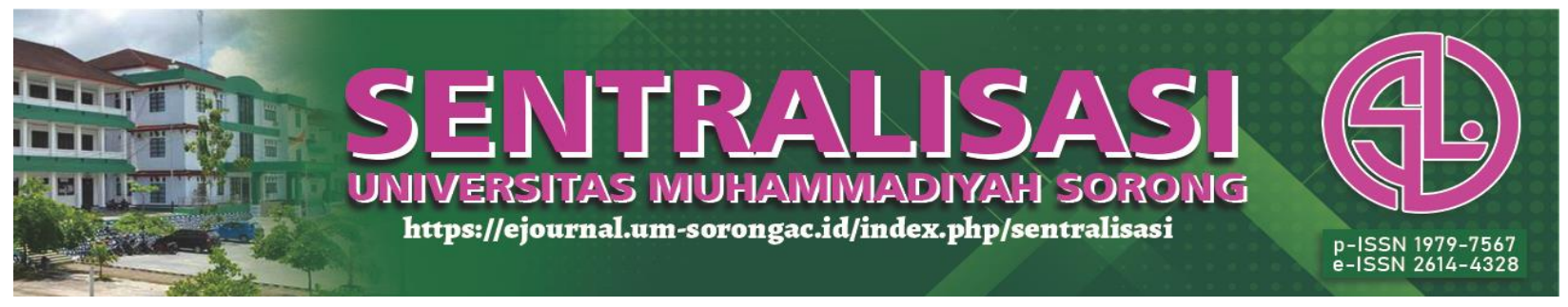

\section{Thank-you note}

In the process of completing this research, the authors would like to thank: 1) Allah swt, who always bestows health and blessings in seeking knowledge. 2) Parents who always provide motivation in studying. 3) The Rector and all the leaders who always give us opportunities and motivation in the implementation of the tridarma of higher education. 4) The parties who participated both as informants and respondents in this research process. 5) Especially to the leaders and managers of journals who have provided opportunities in the process of publishing this journal jurnal.

\section{Reference}

\section{Journal}

Afonasova, Margarita A, Elena E Panfilova, Marina A Galichkina, and Beata Ślusarczyk. 2019. "Digitalization in Economy and Innovation: The Effect on Social and Economic Processes." Polish Journal of Management Studies 19.

Aglietta, Michel. 2000. 28 A Theory of Capitalist Regulation: The US Experience. Verso.

Bonar, James. 1924. "Grundsätze Der Volkswirtschaftslehre.”

Brunnermeier, Markus K, Harold James, and Jean-Pierre Landau. 2019. The Digitalization of Money. National Bureau of Economic Research.

Cai, Fang, and Francis E Warnock. 2006. International Diversification at Home and Abroad. National Bureau of Economic Research.

Chen, James. 2019. "Fiat Money.” Investopedia. Viitattu 9: 2020.

Denning, Stephen. 2016. “Christensen Updates Disruption Theory.” Strategy \& Leadership.

Essuman, Dominic, Nathaniel Boso, and Jonathan Annan. 2020. "Operational Resilience, Disruption, and Efficiency: Conceptual and Empirical Analyses.” International journal of production economics 229: 107762.

Hoppe, Hans-Hermann. 1994. "How Is Fiat Money Possible?-Or, the Devolution of Money and Credit." The Review of Austrian Economics 7(2): 49-74.

Kocherlakota, Narayana R. 1998. "The Technological Role of Fiat Money.” Federal Reserve Bank of Minneapolis Quarterly Review 22: 2-10.

Meera, Ahamed Kameel Mydin. 2002. The Islamic Gold Dinar. Pelanduk Publications Subang 


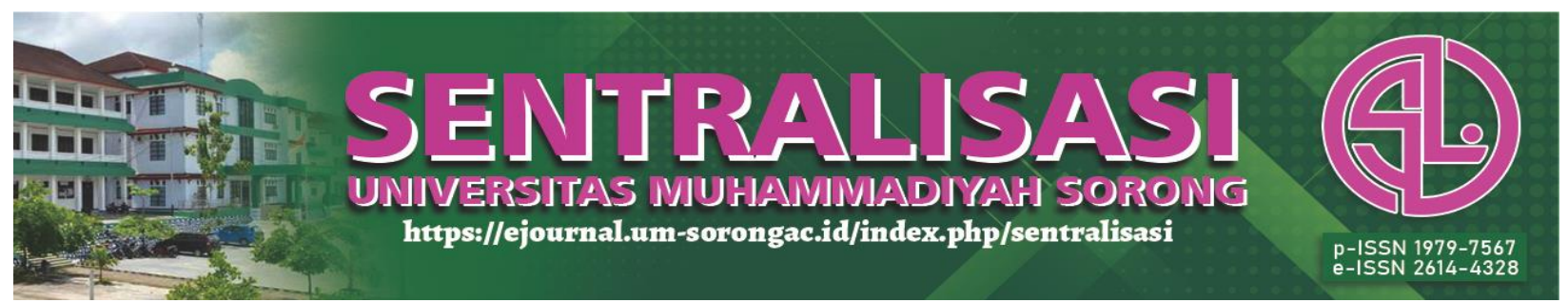

Jaya, Malaysia.

Mulatsih, S Nuning, Aisyah Ratnasari, and Dadang Saepuloh. 2019. "The Role of Gold Dinar And Silver Dirham User Entrepreneurship Community in Dinar-Dirham Replacement Equipment As a Medium of Exchange." KnE Social Sciences.

Ricks, Morgan. 2011. "Regulating Money Creation after the Crisis.” Harv. Bus. L. Rev. 15.

Roth, Felix. 2009. "The Effect of the Financial Crisis on Systemic Trust.” Intereconomics 44(4).

Schlichter, Detlev S. 2014. Paper Money Collapse: The Folly of Elastic Money. John Wiley \& Sons.

Shinohara, Shuji, and Yukio Pegio Gunji. 2001. "Emergence and Collapse of Money through Reciprocity." Applied Mathematics and Computation 117(2-3).

Yasutomi, Ayumu. 1995. "The Emergence and Collapse of Money." Physica D: Nonlinear Phenomena 82(1-2).

\section{Book}

Griffin, Edward. 2000. "The Creature from Jekyll Island.”

Harun, M H. 2007. Fiqh Muamalah. Muhammadiyah University Press.

Kemenag, R I. 2012. “Al-Qur'an Dan Terjemahnya.” Jakarta: PT Sinergi Pustaka Indonesia.

Moleong, Lexy J. 2007. "Metodologi Penelitian Kualitatif Edisi Revisi." Bandung: PT Remaja Rosdakarya 103. 